\title{
PUAKA AND MATARIKI: THE MĀORI NEW YEAR
}

\author{
JIM WILLIAMS (Ngāi Tahu) \\ University of Otago
}

\begin{abstract}
Although New Year is often thought to be a purely European conceptcelebrated in the Northern Hemisphere winter, New Zealand Maori had a similar concept of New Year occurring likewise in the Southern Hemisphere winter or in the middle of the Northern Hemisphere year. In fact, most of the world's peoples have a concept of a New Year, usually in winter, since it is from the shortest day onwards that the rebirth of the year is seen to begin. In recent years there has been increasing focus in New Zealand on the "Māori
\end{abstract} New Year", usually referred to as "Matariki".

The peoples of East Polynesia, in the main, have traditions based on the heliacal (pre-dawn) rising of the Matariki constellation. However, for many peoples of West Polynesia, as well as some New Zealand Māori, it is the star Puaka ${ }^{1}$ (Rigel in Orion) that heralds the New Year (Beattie 1994). Unsurprisingly, Māori were no more homogeneous in their traditional approach to the New Year than they were in other matters and, indeed, throughout Polynesia even within the two main traditions there are various local variations. More specifically, a few Māori groups in the North Island, most of Te Wāipounamu (South Island) and Rekohu (Chatham Islands) have New Year traditions based on Puaka. Elsdon Best wrote: "In the far North, however, also in the South Island and the Chatham Isles, the new year was marked by the cosmic rising of Rigel in Orion" (1986: 11-12). This is Puaka and, while it was the tohu 'sign' of the approaching New Year, the New Year proper commenced at the next new moon.

"Why the two different traditions among Māori?" I recently asked myself, "Does it mean that the groups came from a different homeland?"

After some considered thought, two possibilities occurred to me: either they came from a different homeland or at a different time. In this article I will be exploring the idea that these different annual reckoning systems might be associated with colonists from different time periods, roughly divided into two for the purposes of this essay: an early group who share deep whakapapa and a later group who typically have shorter whakapapa. What I shall refer to as the "Puaka iwi", generally, have a deeper whakapapa, at least in the cases of the people of the Hokianga (Simmons 1976), South Taranaki (Broughton 1979) and Te Wäipounamu (Beattie 1941, Mitchell and Mitchell 2006), where an additional 12 generations, at least, is required to get to the migrating ancestors and, significantly, in each case they have oral traditions concerning the arrival 
of the kümera (Ipomoea batatas) with a subsequent migrants, who I shall refer to as the "Matariki iwi". ${ }^{2}$ Can a case be made tying these points together? Initially, the different geographic origin (West versus East Polynesia) also seemed possible but since this flies in the face of all that is known about Māori origins, I have pursued the hypothesis that a different time seems more likely. Secondly, I wished to examine whether mätauranga Māori 'Māori knowledge' is in accord with academic sources. The evidence that I have gathered from these and other sources is not totally convincing. However, by producing a "work in progress" at this time, I am hoping that others will take the matter further. Perhaps other fields of knowledge will provide more clarity.

\section{PUAKA}

According to traditional Ngāi Tahu thought, Ngā Kapa are the two lines, each of three stars, that in European lore comprise Orion's belt and sword, and Puaka (Rigel) is a single, bright star, a little below and to the right of Ngā Kapa. Puaka changes colour from time to time and twinkles vigorously (Tikao 1990). The old people considered that the stars moved, "setting a little higher each morning" (Tikao 1990: 48).

Puaka... rises about June 6, and is the principal star of the Canterbury Maori... If it comes up on the south side, it is a sign of bad weather, but if it rises on the north side it is a good tohu (omen). Matariki, a group of stars, rises two or three weeks earlier than Puaka, while Ngakapa, a group of stars in a straight line, show the near approach of Puaka, as they rise two or three days before. (Tikao 1990: 49)

If Puaka's rays seem directed to the south that is a sign of bad weather. Beattie elaborated on this, based on information from an elder at Arowhenua, by saying that a stick was placed upright in the ground and watched for several nights. If the star rose to the south it was a sign of good weather, but if it rose to the north it meant bad weather He added that the colour of the star was also important but does not give details (Beattie 1994: 363). ${ }^{3}$

\section{MATARIKI}

Matariki (European Pleiades) is a group of stars that disappears below the horizon in the eastern sky for a few weeks in late April and May each year. Tradition says that the large centre star is an old woman, Matariki, and that the lesser stars of the constellation are her six daughters. Colenso wrote: "I found that the Maori could see more stars in the Pleiades with the unaided eye than I could, for, while I could only see clearly six stars, they could see seven, and sometimes eight" (cited in Best 1972: 52). 


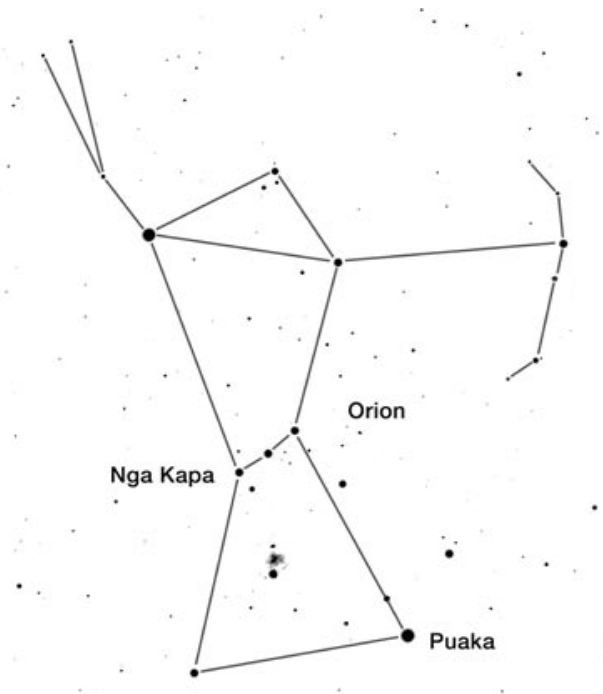

Figure 1. Orion with Nga Kapa and Puaka.

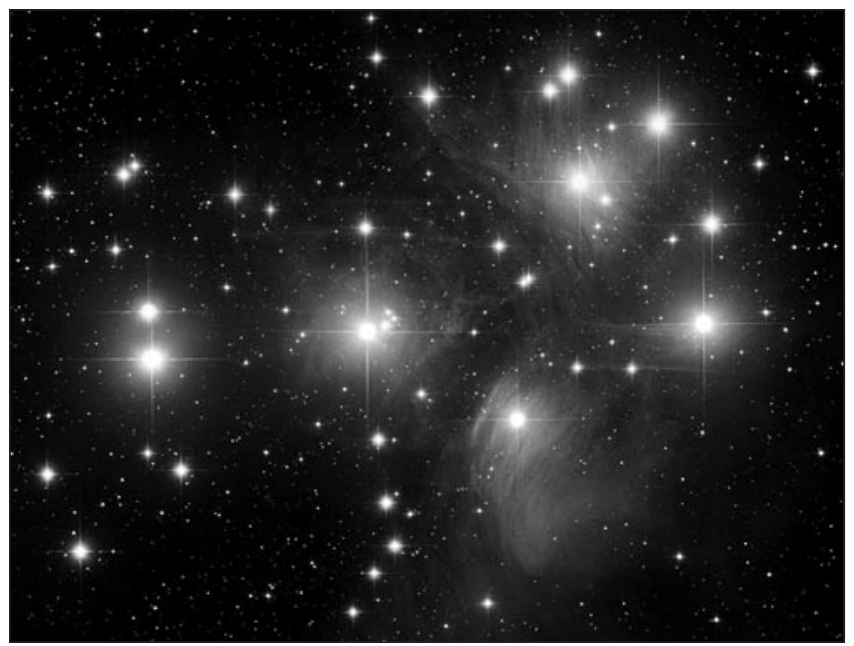

Figure 2. Te Huihuinga a Matariki. (http://antwrp.gsfc.nasa.gov/apod/ap060109.html) 
Astronomers are able to expand on this aspect: Leather and Hall (2004: 63, fn. 2) wrote: "A large telescope reveals about 400 stars", but Eichhorn et al. (1970), using more sophisticated equipment, have identified 502, commenting that "nowhere else in the sky is there a region [with] such a star density" (p. 125). David Jaquiery, of the Beverly Begg Observatory (Dunedin), has advised that the latest estimate is in excess of two thousand stars.

The days between the appearance of Matariki and the new moon a few days later are the Māori equivalent of "April Fool's". People misbehave and even marriage contracts were considered "null and void.... Acts that would normally be unacceptable could not be punished" (Leather and Hall 2004: 63). Best mentions a similar "festival" in "the far north of our North Island" (1986: 15).

The Matariki constellation seems to have captured the imagination worldwide: the Bible, Koran and Talmud all mention the constellation and indeed Matariki features in traditions right round the world, even featuring in the Lascaux Cave paintings in southern France (Andrews 2004). A few abbreviated examples follow; Andrews provides these stories in full, along with a number of others.

- The Pleiades, in Greek myth, were the seven daughters of Pleione and Atlas.

- Australian aborigines refer to the stars as "The Seven Sisters".

- In North America some tribes refer to Matariki as "The Celestial Horse", but most have quite localised stories involving the constellation and various local ancestors, often set during the early years of humankind.

- To the Hindu they were the seven wives of the seven Rishis, or saints.

- In Japan, Matariki is known as "Subaru"; thus the stars as the logo for Subaru Motors.

The reason for Matariki being so important globally, even when not associated with important economic drivers such as the cultivation of vital crops, may be as one Native American elder said: "No, we don't have an important story associated with those stars, though they do come into some of our children's stories, it's just that we can feel their forces" (Anon, pers. comm. September 2007). This is very similar to the idea expressed in The Huarochiri Manuscript (Saloman and Urioste 1991: 37): "They [Pleiades] are the most powerful stars we can feel." It seems not unlikely that these "forces" have been felt worldwide by folk who are close to nature. 


\section{SEASONS}

Tikao noted (1990: 45) that in pre-European times, the Ngāi Tahu year had only three seasons, each denoted by the star that was regarded as being prominent at that time, as follows:

The winter star was Takurua (Sirius) and in many areas it gave its name to the season, which was known as Makariri in the far south;

Summer was the season of Rehua (Antares), as pointed out in the proverb: Ngā kai i taona ai e Rehua. (The foods cooked by Rehua) referring to the fruits that ripen in summer;

The star of autumn was Whānui (Vega).

Takurua incorporated spring, and lasted for six lunar months (Tikao 1990: 45); Raumati or Rehua (Summer) filled three lunar months and Kāhuru or Whanui (Autumn) approximately four (Tikao used the two names for these seasons interchangeably, one referring to the star and the other to the season), the year ending when Puaka re-appeared. Best (1986: 12), cites a Dr Thomson, who said: "The New Zealand year was an imperfect mode of reckoning time, as there could never have been always 13 moons between the appearance of the Puanga star [Rigel] of one year and that of another." In fact, the Lunar months allowed for up to 30 named days but the full 30 were not used in any single month; it was a self-adjusting system with builtin flexibility (Tomoana 1920). This was also the case with the year, which commenced at the new moon following the appearance of Puaka. John White (1887 [3]: 81) explains this with a whakatauki 'proverb': e rua ngà tümā o te humāeko 'the tail of the huia has two odd feathers'. The humāeko is the tail of the huia and was said to have 12 feathers: ten bunched in the centre and two (the tūma) offset, one at each side - a natural phenomenon that indicated some variability on the fringes.

\section{STARS AND WEATHER}

As with Puaka, Matariki is also said to foretell the weather: when nine stars of Matariki stand apart, clearly, a good year will follow; when only six or seven stars seem to be showing and the stars are somewhat fuzzy, the following year will be poor. This portent of weather to come later in the year may well be the reason that Matariki is so closely associated with the planting of kümera ${ }^{4}$ (Ipomoea batatas, sweet potato) (see, for example, Best 1976: 107), as optimum conditions were required in New Zealand for a successful crop. The importance of Matariki is as an indicator of the season to come, thereby determining optimal planting seasons and which years not to plant at all. It must not be thought that Matariki was the actual planting time - this occurred 
when the kowhai (Sophora sp.) bloomed as referred to in the whakataukü: $i$ hea koe i te ao o te kowhai? 'where were you at the time of the kowhai?' (Mead and Grove 2001: 144). By using a natural event to mark planting time, they avoided the arbitrariness of the modern, analogue calendar, which does not adjust for early/late seasons.

Recent research has solidly established the long posited (but often disputed) human interaction between Polynesian voyagers and peoples on the western coast of South America, from whence the kümera was transported into the Pacific by the voyagers (see below). So it is striking that Matariki is used by contemporary Andean potato farmers to predict the agricultural suitability of the coming season with regard to summer rains.

Immediately after the winter solstice, throughout the Andes, hundreds of groups of villagers assemble on high ridges and even the peaks of mountains (Orlove, Chaing and Cane 2002). They wait for the dawn rising of the Pleiades. "The farmers believe that they can use the particular appearance of the Pleiades to forecast the timing and quantity of precipitation that will fall in the rainy season, months later" (p. 428). In fact, Orlove and his colleagues claim to have "uncovered its scientific basis" (p. 428).

Orlove (anthropologist), Chaing (climatologist) and Cane (climatologist) visited the Andes to observe the Pleiades, record precipitation in the following season and to document the associated potato yield. Villagers in the Peruvian and Bolivian Highlands live under constant pressure from altitude and climate, which limit the growing season to rainy months between October and March. However, if soil moisture is too low, seed potatoes will not produce strong shoots, and if the ground freezes the plants will suffer damage. So, at planting time, the farmers need an indication of adequate soil moisture and air temperature during the growing season, in order that their valuable seed not be wasted. The researchers "had a strong hunch that their scheme could be connected with a well-known phenomenon of tropical climate: El Niño" (Orlove et al. 2002: 429), which can affect precipitation during the wet months, but they asked how could it alter the apparent brightness of the Pleiades in June?

[The villagers] look to see whether the cluster is bright or dim,... whether the Pleiades are visible before June 24th... [and] they evaluate the size of the cluster... all closely connected to the relative clarity of the atmosphere.... In years when the Pleiades are bright, large, numerous or otherwise favorable, they plant potatoes at the usual time. However, when the Pleiades are dim, small, scanty or otherwise unfavorable, they anticipate that the rains will arrive late and be sparse, so they postpone planting by several weeks. (Orlove et al. 2002: 430) 
Some of the villagers said that in extreme years they would not plant at all, as they would lose their seed. The similarities to Māori planting of kümera raises the question of whether there could be a common origin for the two sets of traditional practice.

Orlove et al. went on to state that their "earliest firm date for this form of forecasting is the late 16th century" and, accordingly, they "hypothesise that these forecasts do date to pre-Columbian times and represent a survival of ancient Andean traditions" (p. 432).

\section{MATARIKI AND KÜMERA}

On initial consideration, the Puaka and Matariki traditions may seem to suggest a cultural difference and perhaps, therefore, even different origins for the Māori groups that observe them. However, to answer this, it is necessary to first ask: as Puaka is the harbinger of the New Year in the South Island, for Moriori in the Chathams, some folk in South Taranaki and others around the Hokianga and Far North, what do these groups have in common? The answer can perhaps be found in whakapapa 'genealogy' as all speak to an ancient origin, so maybe the when is more important than the whence? Might it be that these "Puaka iwi" could have arrived some generations before those tribes whose reckoning is based on Matariki?

Those tribes, which I call the "Mataliki iwi", arrived later and their whakapapa are of fewer generations. ${ }^{5}$ Over the next few generations, these new arrivals imposed themselves on the earlier "Puaka tribes" throughout the country, as has been asserted by, for example, Ranginui Walker (1990: 45):

Na Toi raua ko Potiki te whenua, na Tuhoe te mana me te rangatiratanga.

The land belonged to Toi and Potiki, the mana and chieftainship belonged to Tuhoe.

The acknowledgement of mana whenua as belonging to the tangata whenua and chieftainship as coming from canoe migrants also occurred in the interior.

The traditions associated with the later arrivals which were certainly many generations after the waka, such as the Uruao, which had brought the earlier arrivals, invariably mention that there were existing inhabitants (which have become widely known as "the tāngata whenua tribes" [Walker 1990]). Taonui (2006) and Mitchell and Mitchell (2006) mention the antiquity of Uruao and even Simmons (1976) attests to the two different depths of whakapapa. Interestingly, there are strong whakapapa links between all the groups mentioned as having a Puaka tradition: the ancestral canoe of Waitaha, Uruao, called in at the Hokianga on its way to Te Wāipounamu, some 45 
generations before 1900. Traditions say that some of the migrants remained there (Beattie 1918: 144, quoting Taare Te Maihäroa), and this is supported by whakapapa from the Hokianga, as well as linguistic evidence (Rameka Cope, pers. comm. 1987). Whakapapa from Te Wāipounamu and the Far North are mutually supportive, both in generation depth and mutual ancestors (see Beattie 1941; also Mohi Tawhai as cited in Beattie 1941). Broughton (1979) contains several South Taranaki whakapapa of similar depth. (I am not suggesting here that whakapapa is a reliable absolute dating system-just that it provides useful relativity between canoe arrivals.)

The Moriori of Rēkohu have a tradition that some of their ancestors were blown from Te Wāipounamu to the Chatham Islands (Tikao 1990: 102). The people known as Rapuwai left Pātea in South Taranaki shortly after the arrival of the Aotea canoe and crossed to Te Wāipounamu to merge with Waitaha.

Turi, captain of the Aotea canoe, and his crew settled among them, in Taranaki. A dispute arose, and some of those involved took seven kos [digging sticks] and stuck them in a point of land jutting out from the coast. This caused the point to become detached from the coast and it floated out to sea carrying six kos with it, leaving the other ko behind on the mainland. The drifting land with the people on it landed at Taumatatini, near Motueka. The six ko turned into a clump of bush which can still be seen at Taumatatini. The leader of these unique voyagers was Raumano and his followers were known as Raumano after him. One of their first settlements was near Te Hoiere (Pelorus Sound) at a place called Raumano, now often called Te Mano-o-te-Rapuwai. They were a prolific people and soon spread inland. They liked nothing better than to settle round lakes as they were fond of eeling, canoeing and swimming, so that the lakes down Westland way soon harboured a large colony of them. When years later the Rapuwai and Kati Mamoe intermarried the name "Patea" reverted to and was used to describe the amalgamated hapus. (Anon. 1930, see also Smith,1910: 127)

Broughton (1979), drawing on whakapapa, suggested that the Aotea arrived 24 generations before 1900 , that is, some 20 generations after the arrival of the Uruao. He also argued persistently that the Aotea arrivals had little impact on Ngā Rauru whakapapa or culture and that Ngā Rauru predated the arrival of the Aotea by seven generations (see p. 10, Genealogy 9 and 10, p. 55).

Traditions from a number of tribal areas attest that the earliest migrants did not bring kümera with them; it was introduced by later arrivals (Best 1976: 24-25, 106-111; for Bay of Plenty, see Pio 1967: 104; for East Coast, North Island, see Tikao 1990: 62; for South Island, see Tikao 1990: 64; for Taranaki, see Smith 1910: 19). Tikao also mentions (p. 62) that at the time of its introduction to New Zealand, kümera was not universally available 
in Hawaiiki, but only grown by a certain group. Such a tradition is quite consistent with the sources above, attesting to kumera being unknown to the earliest migrants. This, and the lack of ubiquity suggested by Tikao, may reflect that kümera was then relatively new, even in East Polynesia. Green (2005) suggested its introduction in the 11th to 12th centuries, a range that sits comfortably between the dates of the very earliest Polynesian migration to New Zealand and the later arrivals of some centuries later. By the time of these later canoes, kümera had become an important commensal and is mentioned in conjunction with many of these canoes (Smith 1910: 87, also see Davidson 1984: 24, and importantly Evans 1997 for Aotea, Horouta, Mataatua, Tainui, Te Arawa and Tokomaru).

Kirch and Green noted (2001: 268-69): "[T]he Ancestral Polynesian lunar calendar was primarily a horticultural calendar, closely linked with the main phases of the yam crop, and with the wet-dry seasonality of the Polynesian homeland region." Strictly, they are correct, given the antiquity and ubiquity of the yam throughout Polynesia. However, in some of East Polynesia, the kümera supplanted the yam as the premier crop and it was the kümera that became of supreme importance to Māori once they had adapted its horticulture to New Zealand conditions and it was cultivation of the kümera that was most closely associated with Matariki.

There now seems to be no doubt that the kumera originated in South America $^{6}$ and was carried westward into the Pacific by human agency (Davidson 1984: 24, Green 2005, Yen 1974: 245). In other words, following initial East Polynesian settlement and perhaps quite early in the East Polynesian settlement period, some Polynesians made contact with South America, secured the sweet potato, and carried it westward, and eventually to New Zealand.

As early as 1938, Te Rangi Hiroa [Peter Buck] posited a South American origin for kümera. He suggests Polynesian agency and a north Peruvian origin, as in the Kechua dialect, of that region, the name kumar is given to the plant (Buck 1938: 314). More recently, Doug Yen, in his seminal study of kümera, established that South America (probably Peru) is the original home of kumera (1974: 248) and that it spread westward from there. Initially, he proposed, the transfer was to Tahiti, the Marquesas and the Cook Islands, and later to the extremities of Polynesia. He suggested that this is likely to have originally occurred early in the second millennium AD (1974: 260). Introduction to New Zealand, he wrote (1974:269), seems to have been around the middle of the 14th century (p. 291) and that this coincides with New Zealand's earliest "storage structures" (p. 269), which he dates AD 1350. Recent DNA testing on chickens in Chile has proven beyond reasonable doubt that Polynesians did in fact reach South America (Storey et al. 2007). Both these researchers and 
Matthews (2006: 96) have pointed out that given "that the Polynesian name kumara is based on an American name for the plant is proof that Polynesian and American people had face to face contact" (Storey et al. 2007: 10335).

Davidson wrote (1984: 24): "The kumara became extremely important in New Zealand, Hawaii and Easter Island, although in historic times it was of little significance in other parts of East Polynesia and probably did not reach West Polynesia at all."

If the close association of Matariki and kümera came from continental South America then that could explain why Matariki had not supplanted Puaka in many of the more western parts of Polynesia. Dates for this transfer of kumera cohere around the 1100-1300 AD period posited by Green (2005: 46) and may be supported by the finding by Kirch and Green (2001: 125 ) that *Mata-liki as a month name is absent from the Fijian and Tongic calendars, but present throughout East Polynesia (supported, for Samoa by Pavihi, pers. comm. 2007). Yams were certainly brought to New Zealand but were of limited importance compared with kümera. Was the importance of Matariki to the cultivation of kumera sufficient that it supplant Puaka as the sign of the New Year? Certainly, this was so on the west coast of Te Wāipounamu, where an aged informant said, "Puaka is our new year. Matariki is an agricultural star [sic]" (cited in Andersen n.d.: 105).

Elsdon Best commented that Māori... "surrounded his [sic] principal cultivated food product with a network of myths, superstitions, tapu, and ritual performances. His procedure in the matter of cultivation of the kumara resembles a religious function" (1976: [7]).

This was likely to be a reflection of the difficulty of growing it at higher latitudes, as there is no evidence of the same intensity of ritual in Island Polynesia.

So, while Matariki and its predictive ability were known in Te Wāipounamu, it did not replace Puaka as harbinger of the New Year-perhaps because kümera did not become a reliable crop through most of the tribal area.

The suggestion that there may be a connection between kümera and a Matariki New Year, and that this may have emanated from South America is not to deny a long Polynesian tradition of Matariki in its own right. Kirch and Green have attested to associations between Pleiades and the green sea turtle (Chelonia mydas) (2001: 260), and between Pleiades and yams (Dioscorea alata, D. esculenta), "a dominant crop in Western Polynesia" (Kirch and Green 2001: 265). In addition, I do not claim that all matauranga associated with kumera is of South American origin. Clearly, much of it developed as the kumera was adapted to New Zealand conditions. We can dismiss, however, Best's claims (1986) that the Pleiades New Year emanates from Asia, particularly since he did not offer any supporting evidence. 
The origins of the traditions may be somewhat obscured by time but many remnants survive and the recent revival of the concept of a "Māori New Year" is certainly an encouragement to further study. It is my hope that this paper will encourage others to research further.

\section{NOTES}

1. North Island Puanga.

2. Most of the whakapapa used have been cross-referred to versions from more than one $i w i$.

3. The astute reader will note a contradiction between the above and the quote from Tikao in the previous paragraph. The inconsistency appears in Beattie 1994: on page 201 south is good and north bad, yet on page 363 the opposite is stated. The main point is that the variability predicts.

4. North Island kümara.

5. What I am calling the "Mataliki iwi" corresponds more or less to the "Great Fleet" as posited by Percy Smith (1910). Smith's story was that the named ancestral waka, which became the names of the tribes, arrived around the middle of the 14th century, or some 24 generation before 1900. Smith's "Great Fleet" story has been largely discredited (see especially Simmons 1976) and for the most part rejected over the past quarter century.

6. Dunis (2005: 94), citing a personal communication from " $[\mathrm{t}]$ he Inca specialist Maria Rostworowski", advised that the very name "kumara" is of South American origin.

\section{REFERENCES}

Andersen, J., n.d. Untitled MS. book of traditional material collected in south Westland. Ms 0148-112, Alexander Turnbull Library, Wellington.

Andrews, Munya, 2004. The Seven Sisters of the Pleiades. Melbourne: Spinifex Press. Anon., 1930. Te Puaho's Raid in 1836. Typescript. MB140, Hii/7, Folio 6. Macmillan Brown Library, Christchurch.

Beattie, J. Herries, 1918. Traditions and legends collected from the natives of Murihiku, Part VIII. Journal of the Polynesian Society 27: 137-61.

1922. Traditions and legends collected from the natives of Murihiku, Part XIV. Journal of the Polynesian Society 32: facing page 193. 1941. Moriori. Dunedin: Otago Daily Times.

1994. Traditional Lifeways of the Southern Maori. Dunedin: University of Otago Press.

Best, Elsdon, 1972. The Astronomical Knowledge of the Maori. Dominion Museum Monograph No. 3. Wellington. 1976. Maori Agriculture. Government Printer: Wellington. 1986. The Maori Division of Time. Dominion Museum Monograph No. 4. Wellington. 
Broughton, Ruka, 1979. The Origins of Ngaa Rauru Kiitahi. English translation of

MA thesis, Victoria University of Wellington.

Buck, Peter H., 1938. Vikings of the Sunrise. Philadelphia: J.P. Lippincott.

Davidson, Janet, 1984. The Prehistory of New Zealand. Auckland: Longman Paul.

Dunis, Serge, 2005. Of kumara and canoes: Maori and Hawaiian mythologies and American contacts. In C. Ballard, P. Brown, M.R. Bourke and T. Harwood (eds), The Sweet Potato in Oceania : A Reappraisal. Sydney: University of Sydney, pp. 89-98.

Eichhorn, Heinrich, William D. Googe, Carl F. Lukac and Kenneth J. Murphy, 1970. Accurate positions of 502 stars in the region of the Pelaides. Memoirs of the Royal Astronomical Society 73: 125-52.

Evans, Jeff, 1997. Ngā Waka o Neherā. Auckland: Reed Books.

Green, R.C., 2005. Sweet potato transfers in Polynesian prehistory. In C. Ballard, P. Brown, M.R.: Harwood (eds), The Sweet Potato in Polynesia: A Reappraisal. University of Sydney, pp. 43-62.

Kirch, Patrick Vinton and Roger C. Green, 2001. Hawaiki: Ancestral Polynesia. Cambridge: Cambridge University Press.

Leather, Kay and Richard Hall, 2004. Tãtai Arorangi: Māori Astronomy-Work of the Gods Paraparaumu:Viking Sevenseas.

Matthews, P.J., 2006. Plant trails in Oceania. In J. Garlick, B. Keane and T Brogfeldt (eds), Te Taiao: Mãori and the Natural World. Wellington, David Bateman, pp. 94-96.

Mead, Hirini Moko and Neil Grove, 2001. Ngā Pēpeha a ngā Tūpuna. Wellington: Victoria University Press.

Mitchell, Hilary and John Mitchell, 2006. Whakatū tribes. In Mãori Peoples of New Zealand: Ngā Iwi o Aotearoa. New Zealand Ministry of Cultural Heritage (comp.). Wellington: David Bateman, pp. 258-63.

Orlove, Benjamin S., John C.H. Chaing and Mark A. Cane, 2002. Ethnoclimatology in the Andes. American Scientist 90 (5): 428-34.

Pio, Hāmiora, 1967. Ko te Ara Tāwhao. In B.G. Biggs, P. Hohepa and S. Mead (eds), Selected Readings in Maori. Wellington: A.H. and A.W. Reed, pp. 104-8.

Saloman, F. and G.L. Urioste (eds), 1991. The Huarochiri Manuscript: A Testament of Ancient and Colonial Andean Religion. Austin: University of Texas Press.

Simmons, D.R., 1976. The Great New Zealand Myth. Wellington: A.H. and A.W. Reed.

Smith, S. Percy, 1910. History and Traditions of the Maoris of the West Coast North Island of New Zealand Prior to 1840. New Plymouth: The Polynesian Society.

Storey, Alice A., Jose Miguel Ramirez, Daniel Quiroz, David V. Burley, David J. Addison, Richard Walter, Atholl J. Anderson, Terry L. Hunt, J. Stephen Athens, Leon Huynen and Elizabeth A. Matisoo-Smith, 2007. Radiocarbon and DNA evidence for a pre-Columbian introduction of Polynesian chickens to Chile. Proceedings of the National Academy of Sciences of the United States of America 104 [June 19]: 10335-39. 
Taonui, Rawiri, 2006. Canoe traditions. In Mãori Peoples of New Zealand: Ngã Iwio Aotearoa. New Zealand Ministry for Culture and Heritage (comp.). Wellington: David Bateman, pp. 56-69.

Tikao, Teone Taare, 1990. Tikao Talks. Auckland: Penguin.

Tomoana, P.H., 1920. Te Aroha o Rangi-nui kia Papa-tua-nuku o te tau 1920: Maori Almanac 1920. Hastings (NZ): A.A. George.

Walker, Ranginui, 1990. Ka Whawhai Tonu Matou: Struggle Without End. Auckland: Penguin Books.

White, John, 1887. Ancient History of the Maori. Wellington: George Didsbury, Government Printer.

Yen, D.E., 1974. The Sweet Potato and Oceania. Bernice P. Bishop Museum Bulletin 236. Honolulu.

\title{
Oral Informants
}

Afamasega Pavihi, Samoan Elder

Barney Jnr Old Coyote, Crow Elder and member Tribal Cultural Committee

David Jaquiery, astronomer, Beverly Begg Observatory, Dunedin

Haman Wise, Shoshone Elder and Tribal Cultural Representative

Rameka Cope, Kaumātua, Te Mahurehure (Hokianga)

Websites

http://antwrp.gsfc.nasa.gov/apod/ap060109.html

\begin{abstract}
Recent years have seen the emergence of regular activities, each June in New Zealand, to coincide with what is usually referred to as "The Māori New Year", generally known as "Matariki". However, within my tribal area, as well as in a number of others, the term "Puaka" was used instead. The article examines these differing tribal traditions and proposes a possible explanation for the two schools of thought.
\end{abstract}

Keywords: Matariki, Puaka, Māori New Year, kūmera/kūmara 